\title{
Doctor of Pharmacy in Jordan: Students' Career Choices, Perceptions and Expectations
}

\author{
Nadine N. Abdelhadi ${ }^{1 *}$, Mayyada Wazaify ${ }^{2}$, Feras W. Darwish Elhajji ${ }^{3}$ and Iman A. Basheti ${ }^{3}$ \\ ${ }^{1}$ Business Park for Project Development, El-Hassan Science City, P.O. Box: 926351, Amman 11190, Jordan \\ ${ }^{2}$ Faculty of Pharmacy, The University of Jordan, Amman-11942, Jordan \\ ${ }^{3}$ Faculty of Pharmacy, Applied Science Private University, P.O. Box 166, Amman 11931, Jordan
}

\begin{abstract}
Purpose: To explore Jordanian Pharm.D students' career choices, perceptions and expectations.
Methods: This observational study was conducted during June 2013 at the University of Jordan. A total of 192 undergraduate Pharm.D students were invited to complete a questionnaire prepared and validated by the research team. The questionnaire investigated student's demographics, the reasons behind choosing to study Pharm.D, satisfaction with the Pharm.D course, student's future plans following graduation, and student's perceptions about the Pharm.D specialty. Data collected were encoded and analyzed by SPSS database for Windows version 17.

Results: The majority (93\%) of respondents was females, aspired to work as hospital clinical pharmacists (83\%) and many $(68 \%)$ believed that Pharm.D graduates are well respected by the general public. Results indicated that students are unaware of the current Pharm.D salaries and have higher expectations than what is being currently offered in the country.

Conclusions: A generation of Pharm.D students from Jordan reported a future aspiration to work as hospital clinical pharmacists. Students have unrealistic salary expectations compared with the current salaries offered in Jordan. 'Awareness workshops' targeting students' knowledge about the Pharm.D degree is required.
\end{abstract}

Keywords: Beliefs, Career Goals, Clinical Pharmacy, Education, Jordan, Pharm.D students.

\section{INTRODUCTION}

Jordan is a Middle Eastern country with a total population of about 7.9 million people [1]. In Jordan, the first 2 pharmacy faculties were public: one at the University of Jordan (JU), and the other at the Jordan University of Science and Technology (JUST) [2]. Now, there are pharmacy faculties at 4 public universities and 8 privately funded universities in the Hashemite Kingdom of Jordan. All schools offer a baccalaureate degree, while only JU and JUST offer Pharm.D degree. The majority of pharmacists in Jordan are working in the private sector. Community pharmacies are considered the most accessible health care facilities by Jordanian patients [2].

A search of the literature revealed few studies in different countries that have explored Pharmacy Students' Career Choices, Perceptions and Expectations. In the UK, majority of students who chose to study pharmacy have made a firm commitment to a career in the profession [3]. Also in the UK, a follow up study showed that a sizeable proportion of pharmacy students do not intend entering the profession for which they have trained, a proportion

*Address correspondence to this author at the Amman 11190, Jordan, P.O. Box: 926351, Jordan; Tel: +962795009089;

E-mail: Nadine_abdelhadi@yahoo.com that is much larger than that estimated by the previous study [4]. In South Africa, only $39 \%$ of students indicated pharmacy as their first choice and $47 \%$ as their second choice. Forty-six percent of the responding students preferred to work at a government hospital, $36 \%$ in industry, and $7 \%, 6 \%$ and $3 \%$ in private hospitals, the retail sector and academia, respectively [5].

In the USA, Pharm.D students showed a more positive outlook regarding future career opportunities than did Bachelor of Science students $(P<.01)$ [6]. Most students were encouraged by someone to pursue pharmacy [7]. Volunteer experiences and work were also important influences [7]. Pharm.D students' career goals upon graduation were found to predominantly be in the retail chain setting [8]. Potential need to generate one's salary was the primary deterrent against considering a career in academic pharmacy among Pharm.D students and autonomy, flexibility, and the ability to shape the future of the profession were the primary motivators [9]. Another study reported that having a controllable work schedule was the variable most strongly associated with career choices for all third year Pharm.D students [10].

In Malaysia, final-year students at Malaysian public universities were most interested in hospital pharmacy practice as their first career step upon graduation, while 
private university students were most interested in community pharmacy [11].

In the Middle East, where pharmacy practice opportunities are similar to that elsewhere in the world [11], the majority of baccalaureate graduates enter community-based practice sites, followed by hospital, industry, and others (e.g. drug regulation and academia) [12]. To the best of knowledge, there have been no published studies in Jordan to explore Pharm.D students' career aspirations, choices and expectations.

\section{AIMS AND OBJECTIVES}

The objective of this study is to explore undergraduate Pharm.D students' career choices, perceptions and expectations and to highlight any change that might have happened throughout the $1 \mathrm{st}$ and 6 th years.

\section{METHODS}

The study was conducted at the University of Jordan (UJ); Faculty of pharmacy. The ethical approval to conduct research was obtained from the Scientific Research Committee at the Faculty of Pharmacy at UJ. All first year and $6^{\text {th }}$ year (final year) Pharm.D students were approached either directly or via telephone to arrange a 15-minutes interview with the researcher at a convenient time.

The study adopted the survey methodology using a self-completed questionnaire. The questionnaire was completed by the participants during the presence of the researcher to improve clarity and to answer any query that may arise. The questionnaire included both closed and open questions. It was prepared by the research team and included 5 parts: Part $A$ : demographic details, Part $B$ : the reasons behind choosing to study Pharm.D Part C: Satisfaction with the Pharm.D course, Part D: Students' future plans following graduation, and Part E: Students' Perceptions about Pharm.D specialty.

In order to ensure face validity, the questionnaire was sent to three academics and three health care professionals with a long professional experience. Their views and comments were considered and then incorporated, where appropriate, into the final version of the questionnaire. To assess test-retest reliability, the questionnaire was administered on two occasions to 15 randomly selected students. The second testing took place two weeks after, and was not included in the final survey analysis. The Test- retest reliability was calculated using Spearman's correlation coefficient ( $r$ ). The rho-value was 0.82 , which implies acceptable testretest reliability.

Respondents were asked to answer a question using the options "true" or "false", to choose an answer from a group of answers, to tick the areas that apply most to them or to rate their response using the options, "Strongly agree", "agree "“neutral", "disagree", "strongly disagree". The study was carried out over a period of two weeks in June 2013.

\section{Data Analysis}

The participants' responses were encoded and All data were entered and analyzed by the Statistical Package for Social Sciences (SPSS, version 17, Chicago, IL, US). Comparisons between groups were performed by independent sample $t$ test or Wilcoxon signed rank test (mean scores); or Chi square test (binary outcome variables). For all analyses, a $p$ value of $<0.05$ was considered significant.

\section{RESULTS}

A total of 192 students completed the questionnaire, giving a response rate of $95 \%$. The majority $(92.6 \%)$ of respondents were females.

Table 1: Students' Demographic Information $(n=192)$

\begin{tabular}{|c|c|}
\hline Demographic information & $\mathbf{N}(\%)$ \\
\hline \multicolumn{2}{|l|}{ Gender } \\
\hline Male & $14(7.4 \%)$ \\
\hline Female & $174(92.6 \%)$ \\
\hline \multicolumn{2}{|l|}{ Age distribution } \\
\hline $17-22$ years & $99(52.4 \%)$ \\
\hline $23-25$ years & $90(47.6 \%)$ \\
\hline \multicolumn{2}{|l|}{ Nationality } \\
\hline Jordanian & $162(90 \%)$ \\
\hline Non-Jordanian: & $18(10 \%)$ \\
\hline Iraqi & $12(6.7 \%)$ \\
\hline Palestinian & $6(3.3 \%)$ \\
\hline \multicolumn{2}{|l|}{ Type of high school } \\
\hline Public school & $83(43.9 \%)$ \\
\hline Private school & $106(56.1 \%)$ \\
\hline \multicolumn{2}{|l|}{ Country of high school certificate } \\
\hline Inside Jordan & $159(86.9 \%)$ \\
\hline Outside Jordan & $24(13.1 \%)$ \\
\hline \multicolumn{2}{|l|}{ Academic year } \\
\hline $1^{\text {st }}$ year & $94(49 \%)$ \\
\hline $6^{\text {th }}$ year & $98(51 \%)$ \\
\hline
\end{tabular}


About $44 \%$ of the respondents were graduates of public schools. First year students constituted of $49 \%$ of the respondents while the rest were sixth year students (Table 1).

Almost $61 \%$ of all students stated that Pharm.D was not their first choice when they applied for university. Of those whom Pharm.D was not their first choice, about $39 \%$ stated that they originally wanted to study medicine and $2.6 \%$ stated that a bachelor of pharmacy and not Pharm.D was their first choice (In Jordan the students can be admitted either to the bachelor of pharmacy program or the Pharm.D program).
About $79 \%$ of students stated that their families have encouraged them to enter the Pharm.D program and almost $31 \%$ of students were influenced by a Pharm.D holder they knew as a role model. About $25.3 \%$ of students were encouraged by their friends and only $11.5 \%$ of the students were advised by their high school teachers to be admitted to the Pharm.D program. Only $13.9 \%$ of the students stated that a visit to the university open day influenced them to choose to study Pharm.D (Table 2).

About $65 \%$ of students stated that they have entered the Pharm.D program because their high grades allowed them to study Pharm.D, and about $69 \%$

Table 2: Reasons Behind Students' Choice to Study Pharm.D.

\begin{tabular}{|c|c|c|c|c|c|}
\hline \multicolumn{2}{|l|}{ STATEMENT/REASON } & \multirow{2}{*}{$\begin{array}{c}\text { First year } \\
25(26.9)\end{array}$} & \multirow{2}{*}{$\begin{array}{c}\text { Sixth year } \\
15(15.6)\end{array}$} & \multirow{2}{*}{$\begin{array}{c}\text { Total } \\
40(21.1)\end{array}$} & \multirow{2}{*}{$\frac{\mathbf{P}^{*} \text {-value }}{.058}$} \\
\hline My family encouraged me & False $n(\%)$ & & & & \\
\hline & True $n(\%)$ & $68(87.1)$ & $15(15.6)$ & $149(78.9)$ & .058 \\
\hline \multirow{2}{*}{$\begin{array}{c}\text { I was influenced by a Pharm.D. I know, as a } \\
\text { role model }\end{array}$} & False $n(\%)$ & $64(68.8)$ & $67(68.4)$ & $131(68.6)$ & .947 \\
\hline & True $n(\%)$ & $29(31.2)$ & $31(31.6)$ & $60(31.4)$ & .947 \\
\hline \multirow[t]{2}{*}{ My friends encouraged me } & False $n(\%)$ & $72(77.4)$ & $70(72.2)$ & $142(74.7)$ & .405 \\
\hline & True $n(\%)$ & $21(22.6)$ & $27(27.8)$ & $48(25.3)$ & .405 \\
\hline \multirow[t]{2}{*}{ A teacher at school advised me } & False $n(\%)$ & $79(85.0)$ & $90(91.8)$ & $169(88.5)$ & .136 \\
\hline & True $n(\%)$ & $14(15.0)$ & $8(8.2)$ & $22(11.5)$ & .136 \\
\hline \multirow[t]{2}{*}{ A visit to a university open day influenced me } & False $n(\%)$ & $69(76.7)$ & $92(94.9)$ & $161(86.1)$ & $<.001$ \\
\hline & True $n(\%)$ & $21(23.3)$ & $5(5.1)$ & $26(13.9)$ & $<.001$ \\
\hline \multirow[t]{2}{*}{ The media (Radio, TV, etc.) influenced me } & False $n(\%)$ & $72(79.1)$ & $85(89.5)$ & $157(84.4)$ & .052 \\
\hline & True $n(\%)$ & $19(20.9)$ & $10(10.5)$ & $29(15.6)$ & .052 \\
\hline \multirow{2}{*}{$\begin{array}{l}\text { Because my high school grades allowed me to } \\
\text { study Pharm.D. }\end{array}$} & False $n(\%)$ & $33(35.1)$ & $34(35.1)$ & $67(35.1)$ & .994 \\
\hline & True $n(\%)$ & $61(64.9)$ & $63(64.9)$ & $124(64.9)$ & .994 \\
\hline \multirow{2}{*}{$\begin{array}{l}\text { I am good at science so I wanted to do a } \\
\text { science based course }\end{array}$} & False $n(\%)$ & $33(35.9)$ & $26(27.1)$ & $59(31.4)$ & .194 \\
\hline & True $n(\%)$ & $59(64.1)$ & $70(72.9)$ & $129(68.6)$ & .194 \\
\hline \multirow[t]{2}{*}{ I wanted to work in a well respected profession } & False $n(\%)$ & $28(30.1)$ & $19(19.4)$ & $47(24.6)$ & .086 \\
\hline & True $n(\%)$ & $65(69.9)$ & $79(80.6)$ & $144(75.4)$ & .086 \\
\hline \multirow{2}{*}{$\begin{array}{l}\text { I wanted a job with good and on demand career } \\
\text { opportunities }\end{array}$} & False $n(\%)$ & $28(29.8)$ & $26(26.5)$ & $54(28.1)$ & .616 \\
\hline & True $n(\%)$ & $66(70.2)$ & $72(73.5)$ & 138 (71.9) & .616 \\
\hline \multirow[t]{2}{*}{ I wanted to work with patients } & False $n(\%)$ & $21(22.3)$ & $28(28.9)$ & $49(25.7)$ & .302 \\
\hline & True $n(\%)$ & $73(77.7)$ & $69(71.1)$ & $142(74.3)$ & .302 \\
\hline \multirow[t]{2}{*}{ I wanted flexible working hours } & False $n(\%)$ & $47(51.1)$ & $48(49.0)$ & $95(50.0)$ & .772 \\
\hline & True n(\%) & $45(48.9)$ & $50(51.0)$ & $95(50.0)$ & .772 \\
\hline \multirow[t]{2}{*}{ I wanted to work in a health related field } & False $n(\%)$ & $16(17.2)$ & $15(18.1)$ & $31(16.2)$ & .722 \\
\hline & True $n(\%)$ & $77(82.8)$ & $83(81.9)$ & $160(83.8)$ & .722 \\
\hline \multirow{2}{*}{$\begin{array}{l}\text { Because it is the closest profession to } \\
\text { Medicine. }\end{array}$} & False $n(\%)$ & $15(16.0)$ & $38(38.8)$ & $53(27.6)$ & $<.001$ \\
\hline & True n(\%) & $79(84.0)$ & $60(61.2)$ & $139(72.4)$ & $<.001$ \\
\hline
\end{tabular}

$\mathrm{p}^{*}$ : is comparing first year and sixth year; Chi square test. 
stated that they chose Pharm.D because they were good at science and wanted to study a science based course. Working in a well-respected profession was the driver for the majority of the respondents $(75 \%)$ to enter the Pharm.D program. A majority of students $(71.9 \%)$ stated that they entered the Pharm.D program because they looked for a job with good career opportunities. Many $(74 \%)$ stated that they entered the Pharm.D program as they wanted to work with patients. Having a flexible job with regards to the working hours was a driver for almost half of the students to enter the Pharm.D program. Working in a health related field excited the majority of the students $(83.8 \%)$ to enter the Pharm.D program (Table 2).

\section{Students' Satisfaction with the Pharm.D Course}

Most of the students (66 \%) believed that they didn't understand what Pharm.D meant when they entered the pharmacy school, while about $55 \%$ stated that they are currently happy with studying Pharm.D. Almost $20 \%$ of students regretted entering pharmacy school and almost $23 \%$ regretted choosing Pharm.D as a specialty (Table 3 ).

\section{Students' Future Plans Following Graduation (Career Choices)}

Most of the students $(83.2 \%)$ stated that they did not desire to work in a hospital pharmacy and the majority $(82.8 \%)$ favored working as a hospital clinical pharmacist. Results were similar regarding working in a community pharmacy, were about $81 \%$ stated that they did not want to work in such a field.

About $54 \%$ of the students reported that they intend to work outside of Jordan following graduation. Most of the students $(94.7 \%)$ stated that they were sure regarding their future career and most of them $(98.4 \%)$ intended to work in the field (Table 4).

\section{Students' Perceptions about Pharm.D. as a Profession (Career Expectation)}

The majority of students $(90.9 \%)$ believed that Pharm.D should be a well-paid job. Almost $68 \%$ of students believed that Pharm.D graduates are well respected by the general public. Although $(82.8 \%)$ of students planned to work in a hospital as clinical

Table 3: Students' Satisfaction with the Pharm.D Course

\begin{tabular}{|c|c|c|c|c|c|}
\hline \multicolumn{2}{|c|}{ Statement } & \multirow{2}{*}{$\frac{\text { First year }}{20(21.7)}$} & \multirow{2}{*}{$\begin{array}{c}\text { Sixth year } \\
46(46.9)\end{array}$} & \multirow{2}{*}{$\frac{\text { Total }}{266(34.7)}$} & \multirow{2}{*}{$\frac{\mathbf{P}^{*} \text {-value }}{.001}$} \\
\hline I clearly understood what & Strongly Disagree/ Disagree $\mathrm{n}(\%)$ & & & & \\
\hline entered the pharmacy school. & Neutral n(\%) & $31(33.7)$ & $18(18.4)$ & $49(25.8)$ & .001 \\
\hline & Strongly Agree /Agree n(\%) & $41(44.6)$ & $34(34.7)$ & $75(39.5)$ & .001 \\
\hline \multirow{3}{*}{$\begin{array}{l}\text { I am currently happy with } \\
\text { studying Pharm.D. }\end{array}$} & Strongly Disagree/ Disagree $\mathrm{n}(\%)$ & $9(9.7)$ & $21(21.6)$ & $30(15.8)$ & .040 \\
\hline & Neutral n(\%) & $24(25.8)$ & $32(33.0)$ & $56(29.5)$ & .040 \\
\hline & Strongly Agree /Agree $\mathrm{n}(\%)$ & $60(64.5)$ & $41(45.4)$ & $104(54.7)$ & .040 \\
\hline \multirow{3}{*}{$\begin{array}{c}\text { I am happy with working } \\
\text { towards a career as a } \\
\text { Pharm.D. }\end{array}$} & Strongly Disagree/ Disagree n(\%) & $7(7.6)$ & $15(15.6)$ & $22(11.7)$ & .215 \\
\hline & Neutral $n(\%)$ & 19(20.6) & $26(27.1)$ & $45(24.0)$ & .215 \\
\hline & Strongly Agree /Agree $\mathrm{n}(\%)$ & $66(71.8)$ & $55(57.3)$ & $121(64.3)$ & .215 \\
\hline \multirow{3}{*}{$\begin{array}{l}\text { Future salary does not play a } \\
\text { part in my satisfaction with } \\
\text { studying Pharm.D. }\end{array}$} & Strongly Disagree/ Disagree $\mathrm{n}(\%)$ & $32(34.8)$ & $42(43)$ & $74(39.2)$ & .695 \\
\hline & Neutral $n(\%)$ & $24(26.1)$ & $21(21.6)$ & $45(23.8)$ & .695 \\
\hline & Strongly Agree /Agree n(\%) & $36(39.1)$ & $34(35.1)$ & $70(37)$ & .695 \\
\hline \multirow{3}{*}{$\begin{array}{l}\text { I regret entering pharmacy } \\
\text { school. }\end{array}$} & Strongly Disagree/ Disagree $\mathrm{n}(\%)$ & $62(68.1)$ & $48(49)$ & $110(58.2)$ & .002 \\
\hline & Neutral n(\%) & $15(16.5)$ & $27(27.6)$ & $42(22.2)$ & .002 \\
\hline & Strongly Agree /Agree n(\%) & $14(15.4)$ & $23(23.4)$ & $37(19.6)$ & .002 \\
\hline \multirow{3}{*}{$\begin{array}{l}\text { I regret choosing pharm.D. as } \\
\text { a specialty. }\end{array}$} & Strongly Disagree/ Disagree $\mathrm{n}(\%)$ & $62(66.7)$ & $37(37.7)$ & $99(51.8)$ & $<.001$ \\
\hline & Neutral n(\%) & $21(22.6)$ & $28(28.6)$ & $49(25.6)$ & $<.001$ \\
\hline & Strongly Agree /Agree n(\%) & $10(12.7)$ & $33(33.7)$ & $43(22.6)$ & $<.001$ \\
\hline
\end{tabular}

$\mathrm{p}^{*}$ : is comparing first year and sixth year; Chi square test. 
Table 4: Students' Future Plans Following Graduation. Students were Asked to Tick the Areas that Apply Most to them

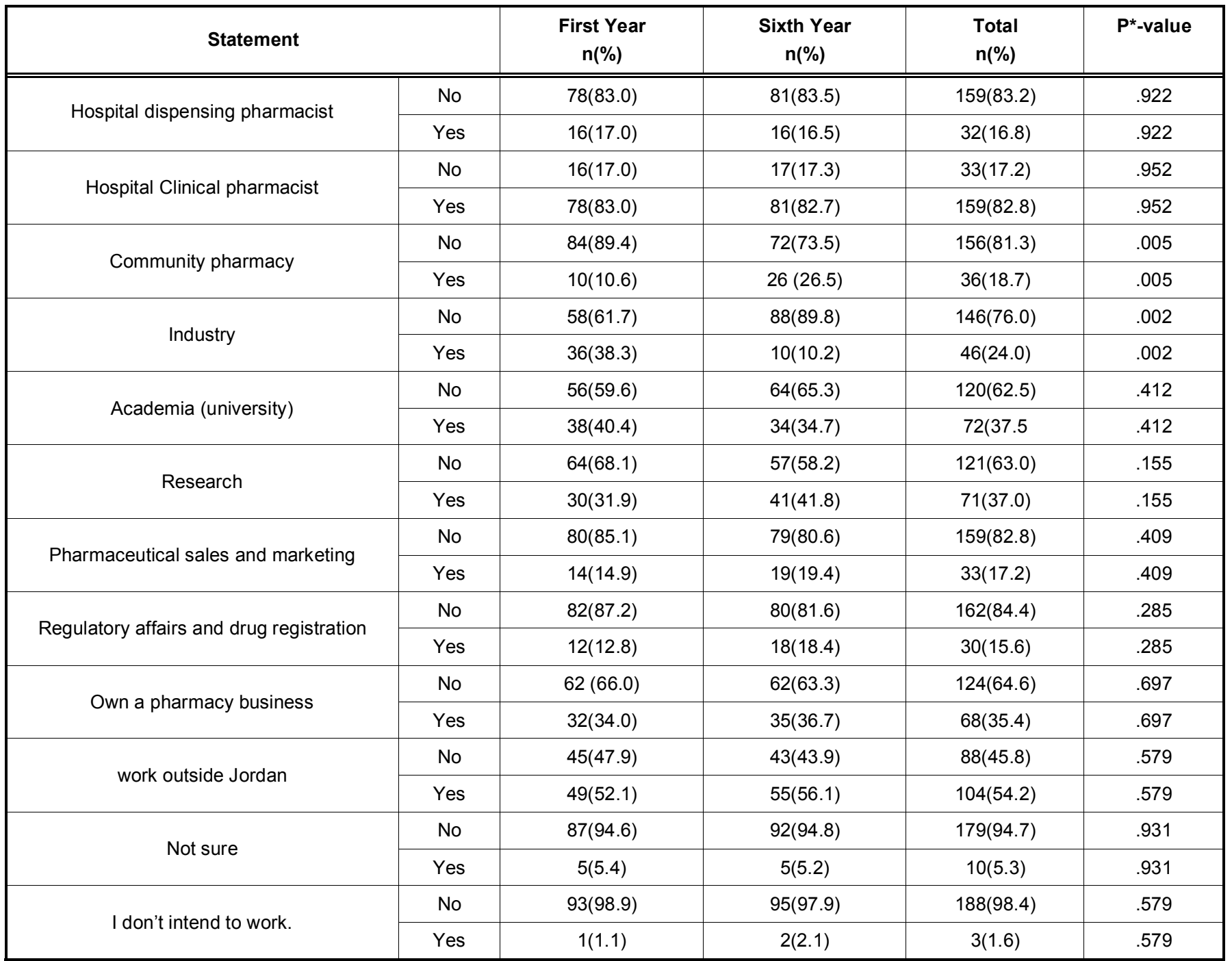

$\mathrm{p}^{*}$ : is comparing first year and sixth year; Chi square test.

Table 5: Students' Perceptions about Pharm.D. Specialty

\begin{tabular}{|c|c|c|c|c|c|}
\hline \multicolumn{2}{|l|}{ Statement } & $\begin{array}{c}\text { First Year } \\
\mathrm{n}(\%)\end{array}$ & $\begin{array}{c}\text { Sixth Year } \\
n(\%)\end{array}$ & $\begin{array}{l}\text { Total } \\
n(\%)\end{array}$ & $P^{*}$-value \\
\hline \multirow{2}{*}{ Pharm.D. should be a well paid job } & False & $11(12.2)$ & $6(6.2)$ & $17(9.1)$ & .151 \\
\hline & True & $79(87.8)$ & $91(93.8)$ & $170(90.9)$ & .151 \\
\hline \multirow{2}{*}{ Pharm.D. graduates should only work in hospitals. } & False & $62(67.7)$ & $66(68.0)$ & $128(67.4)$ & .840 \\
\hline & True & $31(32.3)$ & $31(32.0)$ & $62(32.6)$ & .840 \\
\hline \multirow{2}{*}{$\begin{array}{l}\text { Pharm.D. graduates are well respected by the general } \\
\text { public }\end{array}$} & False & 29(31.9) & $31(31.6)$ & $60(31.7)$ & .972 \\
\hline & True & $62(68.1)$ & $67(68.4)$ & $129(68.3)$ & .972 \\
\hline \multirow{2}{*}{$\begin{array}{c}\text { Pharm.D. graduates are different than Pharmacy } \\
\text { graduates }\end{array}$} & False & 14(15.1) & $16(16.5)$ & $30(15.8)$ & .785 \\
\hline & True & $79(84.9)$ & $81(83.5)$ & $160(84.2)$ & .785 \\
\hline \multirow{2}{*}{$\begin{array}{l}\text { Pharm.D. graduates are different than Masters in Clinical } \\
\text { Pharmacy graduates }\end{array}$} & False & $32(34.4)$ & $53(54.6)$ & $85(44.7)$ & .005 \\
\hline & True & $61(65.6)$ & $44(45.4)$ & $105(55.3)$ & .005 \\
\hline
\end{tabular}

$\mathrm{p}^{*}$ :is comparing first year and sixth year; Chi square test. 
pharmacists, only $33 \%$ expected to actually work in hospitals (Table $\mathbf{5}$ ).

\section{DISCUSSION}

This study revealed vital information for the future of the Pharm.D degree in Jordan. Lack of student's knowledge about the degree, and naïve high expectations when it comes to the place of work (hospital and not community) and rate of salary are important issues that need to be dealt with quickly.

The majority of students $(61 \%)$ stated that Pharm.D was not their first choice when they applied for university, which is similar to what have been reported in South Africa. Many (66\%) believed that they didn't understand what Pharm.D meant when they entered the pharmacy school. This can be explained by the lack of career awareness activities in Jordan. Majority (82.8 $\%$ ) of the students wanted to work as a hospital clinical pharmacist and many didn't (81\%) want to work in a community pharmacy. Nearly all respondents $(90.9 \%)$ reported that Pharm.D. should be a well-paid job.

The majority of students didn't understand what is meant by Pharm.D when they entered the pharmacy school,

Majority of students chose the Pharm.D program because they wanted a job with a good and on demand career opportunities. The career opportunities for Pharm.D graduates varies depending on whether he/she tends to work inside of Jordan where the career opportunities for Pharm.D, especially those aspiring to work as a hospital clinical pharmacist, are scarce in comparison to the number of graduates. The majority of the students believed that Pharm.D jobs are well paid, and this is not the case for those aspiring to work in hospitals and in community pharmacies inside Jordan.

About 60 percent of students $(60.5 \%)$ entered Pharm.D having failed to achieve entry to their first choice subject, which was medicine in most of the cases. In addition, most of the students aspired to work with patients, being one of their main reasons to study Pharm.D, the closest profession to medicine. This explains the high tendency among students to aspire working as a hospital clinical pharmacist.

Career awareness activities are vitally needed to educate the students about the program at the time of entry and about the career opportunities especially for those who have the intention to work inside of Jordan.
The fact that majority of students did not want to work in community pharmacies, while most available job opportunities in Jordan are in community pharmacies, is an issue that need to be addressed immediately. Further similar research is needed in pharmacy and other specialties in Jordan for effective task force planning.

\section{LIMITATIONS OF THE STUDY}

Although the response rate was high, like any other survey, the main limitations of the study were:

1. Since this study was conducted at one university in Jordan and on a relatively small sample size, it would be difficult to generalize the data to other universities in Jordan.

2. Although every effort was made to minimize the social desirability bias, an opportunity for respondents to give false answers in order to please the pharmacist researcher still existed.

\section{CONCLUSION}

A generation of Pharm.D students from Jordan reported a future aspiration to work as hospital clinical pharmacists. The majority of Pharm.D students did not clearly understand what was meant by Pharm.D when they entered the program. Students reported unrealistic salary expectations compared with the current salaries offered in Jordan. 'Awareness workshops' targeting students' knowledge about the Pharm.D degree is required.

\section{ACKNOWLEDGEMENTS}

The authors would like to thank the Faculty of Pharmacy at the University of Jordan for facilitating this project. Special thanks go to Dr. Rana abu dahab, Dr. Al-Motassem Fahmi and Dr. Mayyada Shehada from $\mathrm{JU}$ for their valuable cooperation.

\section{REFERENCES}

[1] Central Intelligence Agency. World Fact Book 2004: Jordan [accessed June 6, 2014]. Available from: https://www.cia. gov/library/publications/the-world-factbook/geos/jo.html

[2] Al-Wazaify M, Matowe L, Albsoul-Younes A, Al-Omran O. Pharmacy Education in Jordan, Saudi Arabia, and Kuwait. Am J Pharm Educ 2006; 2: [accessed June 6, 2014]. Available from: http://www.ncbi.nlm.nih.gov/pmc/articles/ PMC1636892/pdf/ajpe18.pdf

[3] Wilson K, Jesson J, Langley C, Hatfield K, Clarke L. Pharmacy Undergraduate Students: Career Choices \& Expectations across a Four-Year Degree Programme. Birmingham: Royal Pharmaceutical Society of Great Britain; 2006 August [accessed June 6, 2014]. Available from: 
file://C:/Users/user/Downloads/Career\%20Choices $\% 20 \& \% 2$ 0Expectations \%20 (2).pdf

[4] Willis S, Hassell K, Noyce P. Career intentions of pharmacy students. J Health Servic Res Policy 2008; (13 Suppl 2): S45-51.

http://dx.doi.org/10.1258/jhsrp.2007.007112

[5] Modipa SI, Dambisya YM. Profile and career preferences of pharmacy students at the University of Limpopo, Turfloop Campus, South Africa. Educ Health (Abingdon) 2008; 21: [accessed June 6, 2014]. Available from: http://www.educationforhealth.net/temp/EducHealth213164-3946867_ 105748.pdf.

[6] Baran RW, Shaw J, Crumlish K. Pharmacy student expectations for professional practice. Manag Care Interface. 1998; 11(8): 50-5.

[7] Anderson D, Sheffield M, Massey Hill A, Cobb H. Influences on Pharmacy Students' Decision to Pursue a Doctor of Pharmacy American Journal of Pharmaceutical Education 2008; 72: [accessed June 6, 2014]. Available from: http:// www.ncbi.nlm.nih.gov/pmc/articles/PMC2384197/pdf/ajpe22. pdf.

[8] Savage L, Beall J, Woolley T. Factors That Influence the Career Goals of Pharmacy Students. Am J Pharmac Educ 2009; [accessed June 6, 2014]. Available from: http://www.ncbi.nlm.nih.gov/pmc/articles/PMC269 0887/puff/ ajpe28.pdf.

[9] Sheaffer E, Brown B, Byrd D, Gupchup G, Mark S, Mobley Smith M, Rospond R. Variables Impacting an Academic Pharmacy Career Choice. Am J Pharmac Educ 2008; 72: [accessed June 6, 2014]. Available from: http://www.ncbi. nlm.nih.gov/pmc/articles/PMC2508718/pdf/ajpe49.pdf http://dx.doi.org/10.5688/aj720349

[10] Siracuse M, Schondel Meyer S, Hadsall R, Schommer J. Third-Year Pharmacy Students' Work Experience and Attitudes and Perceptions of the Pharmacy Profession. Am J Pharmac Educ 2008; 72: [accessed June 6, 2014]. Available from: http://www.ncbi.nlm.nih.gov/pmc/articles/PMC2508721/ pdf/ajpe50.pdf. http://dx.doi.org/10.5688/aj720350

[11] Hasan S, Weng Kwai Chong D, Ahmadi K, Pei Se W, Hassali M, PhD, Hata E, Abdul Hadi M, Sridhar S, Ahmed S, Yean L, Efendie B. Influences on Malaysian Pharmacy Students' Career Preferences. Am J Pharmac Educ 2010; 74: [accessed June 6, 2014]. Available from: http://www.ncbi. nlm.nih.gov/pmc/articles/PMC2996756/pdf/ajpe166.pdf http://dx.doi.org/10.5688/aj7409166
[12] Kheir N, Zaidan M, Younes H, El Hajj M, Wilbur K, Jewesson P. Pharmacy Education and Practice in 13 Middle Eastern Countries. Am J Pharmac Educ 2008; 72: [accessed June 6, 2014]. Available from: http://www.ncbi.nlm.nih.gov/pmc/ articles/PMC2661169/pdf/ajpe133.pdf http://dx.doi.org/10.5688/aj7206133

[13] Wilson K, Jesson J, Langley C, Clarke L, Hatfield K. MPharm Programmes: Where are we now? Britain: Pharmacy Practice Research Trust 2005 Sept [accessed June 6, 2014]. Available from: www.aston.ac.uk/EasySiteWeb/GatewayLink. aspx?alld=24240.

[14] Contractual Framework for Community Pharmacy. London: Department of Health; 2004 Oct [accessed June 6, 2014] Available from: http://webarchive.nationalarchives.gov.uk/+/ www.dh.gov.uk/en/Publicationsandstatistics/Publications/Pub licationsPolicyAndGuidance/DH_4091867

[15] Seston L, Hassell K. Pharmacy Workforce census 2008: Main Findings. Manchester: Royal Pharmaceutical Society of Great Britain; 2008 Jul [accessed June 6, 2014]. Available from: http://www.rpharms.com/about-pharmacy-pdfs/ census08.pdf

[16] Collins English Dictionary. 10th ed. London: Harper Collins, 2009.

[17] Jesson J, Wilson K, Langley C, Hatfield K. Images of pharmacy as a career: a survey among groups of year 12 students at school. The Pharmaceutical Journal 2008; 280: [accessed June 6, 2014]. Available from: http://www.pharmaceutical-journal.com//opinion/comment/ images-of-pharmacy-as-a-career-a-survey-among-groups-ofyear-12-students-at-school/10006084.fullarticle.

[18] Silverthorne J, Price G, Hanning L, Cantrill J. Factors that influence the career choices of pharmacy undergraduates. Pharm Educ 2003; 3(3): 161-167. http://dx.doi.org/10.1080/15602210310001623124

[19] Cockerill R, Tanner J. Choosing pharmacy: the impact of gender, race and cohort on career decision. J Soc Admin Pharm 2001; 18(3): 111-5.

[20] Audin K, Davy J, Barkham M. University Quality of Life and Learning (UNIQoLL): an approach to student well-being, satisfaction and institutional change. J Further Higher Educ 2003; 27(4): 365-382. http://dx.doi.org/10.1080/0309877032000128073 